\title{
Characterization of occupational exposure to pesticides and its impact on the health of rural women
}

\author{
Carolina Panis ${ }^{1 *}$ (1), Shaiane Carla Gaboardi ${ }^{2}$ (D), Aedra Carla Bufalo Kawassaki ${ }^{1}$ (D),

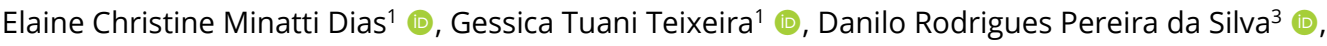 \\ Daniel Rech ${ }^{1}$ (1), Luciano Zanetti Pessôa Candiotto² (B) \\ ${ }^{1}$ Programa de Pós-Graduação em Ciências Aplicadas à Saúde, Universidade Estadual do Oeste do Paraná (UNIOESTE), \\ Francisco Beltrão, PR, Brasil \\ ²Programa de Pós-Graduação em Geografia, Universidade Estadual do Oeste do Paraná (UNIOESTE), Francisco Beltrão, PR, \\ Brasil \\ ${ }^{3}$ Departamento de Educação Física, Universidade Federal de Sergipe, São Cristóvão, SE, Brasil \\ *Corresponding author: carolpanis@hotmail.com
}

\begin{abstract}
Objective: To characterize the profile of occupational exposure to pesticides and its impact on women's health. Method: This is a prospective and descriptive study with a quantitative approach. The study population included all patients attended at Francisco Beltrao Cancer Hospital (Ceonc) from May 2015 to December $2018(n=315)$. The characterization of their exposure profile was obtained through an interview using a form applied by trained researchers contained 60 questions related to women's pesticide exposure and their health status. The questions referred to past and current occupational pesticide exposure profile, intoxication, and health history from women and their families. All collected data were analyzed in the Statistical Package for the Social Sciences package (SPSS 25.0). Results: A total of 265 individuals (84.2\%) have lived some part of their life in the countryside, and $70 \%$ were categorized as occupationally exposed to pesticides. Most of them (57\%) were directly exposed, mainly by washing pesticide-contaminated clothes and personal protective equipment used in pesticide pulverization without glove protection. Cancer cases in the family were the main disease reported (68.3\%). Further, $57 \%$ of interviewed women had a breast cancer diagnosis but no significance between breast cancer occurrence and pesticide exposure was observed. Conclusion: The form allowed us to characterize the profile of occupational pesticide exposition in rural women, alerting them to their severe contamination. This approach can be useful to characterize the occupational exposure profiles of rural workers living in other rural regions of Brazil that use pesticides.
\end{abstract}

Keywords: pesticides, occupational exposure, breast cancer.

\section{How to cite}

Panis C, Gaboardi SC, Kawassaki ACB, Dias ECM, Teixeira GT, Silva DRP, Candiotto LZP.

Characterization of occupational exposure to pesticides and its impact on the health of rural women. Rev Ciênc Farm Básica Apl. 2022;43:e748. https://doi.org/10.4322/2179-443X.0748.

Financial support: Programa de Apoio à Pesquisa no SUS, edital 2016.

Conflicts of interest: None declared.

The study was carried out at Universidade Estadual do Oeste do Paraná (UNIOESTE), Francisco Beltrão, PR, Brasil.

Received on August 23, 2021. Accepted on December 06, 2021 


\section{INTRODUCTION}

Brazil figures on the international scene as one of the largest pesticide consumers in the world ${ }^{1}$. The demand for products such as animal feed and vegetable oil in China, India, and Southeast Asia raised soybean production in Latin America significantly from the 2000s onwards. This scenario improved the use of genetically modified organisms leading to significant increase use of pesticides ${ }^{2,3}$. Soybean, sugar cane, corn, and cotton monocultures have corresponded for more than $80 \%$ of the pesticides consumed in the country, and a growing over $100 \%$ has been registered between 2009 and $2019^{4}$. Since 2014, Brazil has traded more than 500 tons of pesticides per year, and about $30 \%$ of this volume has been used in the South region of the country, which includes Paraná, Santa Catarina, and the Rio Grande do Sul states 5 .

A lot of pesticides, classified as insecticides, miticides, herbicides, nematicides, fungicides, molluscicides, and rodenticides ${ }^{6}$, are considered dangerous and have been traded in Brazil, despite international agencies' warnings. This fact has contributed to the growing scientific and political debates about the possible negative effects of the continuous use of these products on people's health. Pignati et al. (2017) described a positive association between pesticide exposure and the occurrence of acute, sub-acute, and chronic poisonings in Brazilians ${ }^{7}$.

Occupational exposure to pesticides has been associated with increased risk of several diseases such as cancer ${ }^{8-10}$, mental illness ${ }^{11}$, endocrine disorders ${ }^{12}$, and autoimmune pathologies ${ }^{13}$. However, even though the exposure is not direct, as occurs with pesticide applicators, residents of rural areas may present significant symptoms as respiratory problems and altered lung function after pesticide application in the surrounding fields ${ }^{14}$. In addition, the use of pesticides also leads to contamination of soil ${ }^{15 ; 16}$, water ${ }^{17 ; 18}$ and food ${ }^{19}$, which further compromises the health of all living beings.

There is a great challenge for the awareness of rural workers and their families concerning the health risks inherent to exposure to pesticides. The search for sharing knowledge regarding this issue is global and led to the creation of documents such as the World Health Organization (WHO) guideline on health workforce development, attraction, recruitment, and retention in rural and remote areas ${ }^{20}$, which provides pivotal information and recommendations on how to help prevent and reduce pesticide exposure.

The Brazilian Society of Public Health (ABRASCO) published an extensive document reporting the deleterious effects of pesticide contamination on Brazilian communities' health and the environment ${ }^{21}$. Besides, the International Cancer Research Agency (IARC) published in 2015 a consensus that categorized the herbicide glyphosate and the insecticides malathion and diazinon, largely used in Brazil, as probably carcinogenic to humans 22 .

Considering that the health profile of chronically pesticide exposed rural workers is poorly described in Brazil, we conducted a survey to characterize it in a female population from Southwest Paraná, which englobes some of the largest pesticide consumers in the state. To reach this goal, we proposed a form containing questions to characterize the past and current profiles of occupational pesticide exposure and collect information about the health status of the interviewed women and their families.

\section{METHODS}

\section{Ethical aspects}

The research that originated this article was approved by the Institutional Ethics Committee of Unioeste under the number CAAE 35524814.4.0000.0107. 


\section{Study area}

The state of Paraná is the second-largest producer of soybean in Brazil and has stood out as one of the largest consumers of pesticides, especially glyphosate. Paraná is currently the fourth state in the federation that uses pesticides most in its crops ${ }^{5}$ since only the states of Mato Grosso, São Paulo, and the Rio Grande do Sul have used more pesticides.

According to data from the Monitoring System of Agrochemicals Trade and Use in Paraná (SIAGRO), since 2013, in Paraná it has been traded annually between 90 and 100 thousand tons of pesticides ${ }^{23}$. The Southwest Paraná Mesoregion is the fourth region with the largest soybean harvested area in the state and the seventh in pesticide consumption ${ }^{24}$. Currently, according to the Institute for Economic and Social Development of Paraná State (IPARDES) data, agricultural production has a significant portion in the composition of Gross Domestic Product (GDP) of the municipalities that make up this region ${ }^{25}$. In 2017 agricultural activity generated the highest GDP in approximately 50\% of the municipalities. This production has demanded about seven thousand tons of pesticides per year.

Considering just 27 of the 37 municipalities of Southwest Paraná, that compose Eighth Paraná Regional Health, more than 4,000 tons of pesticide have been used since 2013. In 2014, the commercialization of pesticides per cultivated area was $6.7 \mathrm{~kg}$ per hectare ${ }^{26}$. However, when averaging the volume of pesticides traded per agricultural or agricultural area cultivated between 2012 and 2018, in more than 50\% of the municipalities that make up the Paraná Eighth Regional Health, the result per hectare was higher, reaching up to $20 \mathrm{~kg}$ per hectare, that corresponds to $10,000 \mathrm{~m}^{2}$ (Figure 1).

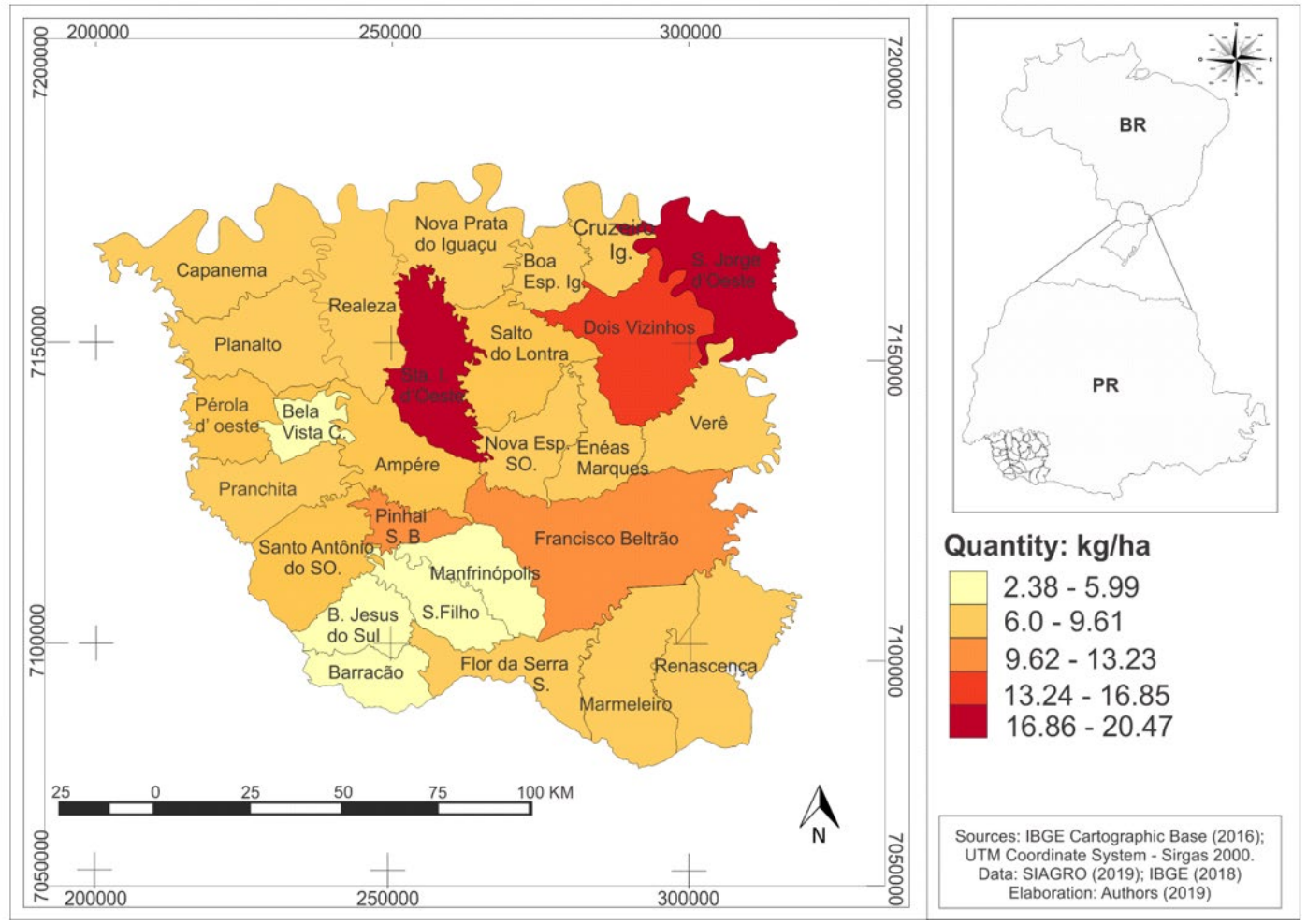

Figure 1 - Mean volume of pesticides ( $\mathrm{kg}$ ) per cultivated area (hectare) used annually in the 27 municipalities of Southwest Paraná (2012-2017) included in the study.

The growing consumption of pesticides in these 27 municipalities located in the Southwest of Paraná is proportional to the increase in monocultures and transgenic crops, especially 
soybean and corn. According to IBGE data, in 2017, the trinomial soybean, corn, and wheat corresponded to $93 \%$ of the harvested area of the main grains produced in this study area ${ }^{27}$.

In Southwest Paraná, these three cultures require at least 10 applications ${ }^{28}$ per crop, which includes twice desiccation of all existing vegetation cover before planting, administration of fungicide up to four times per harvest, in addition to application to every time an insect or spontaneous plant may compromise the crop.

\section{Study design and patient selection}

This study is prospective, descriptive, and has a quantitative approach. The research has included women who attended Francisco Beltrao Cancer Hospital (Ceonc) from May 2015 to December 2018. Ceonc is a public Oncology hospital that gathers a great number of women from all the 27 municipalities included in the $8^{\text {th }}$ Health Regional of Paraná state for breast cancer screening each year. The study was conducted aiming to reach both cancer and non-cancer patients, occupationally exposed or not to pesticides. It has been included only breast cancer patients (no other cancers) because it was the main neoplasia predominant in the studied population. The confirmation of breast cancer diagnosis was obtained from medical records, kindly provided by the hospital.

A total of 315 women aged from 18 to 79 years old signed a term of free and informed consent. All women who attended in the period that accepted to join the study were included. Those that did not volunteer or did not sign the consent form were excluded.

\section{Form design and collection of pesticides exposure profiles}

A form (Supplementary Material) was conceptualized based on the experience of authors regarding the agrarian spatial and social configuration in the studied region. This form was designed to identify aspects regarding pesticide exposure from the interviewed women and their families, in the present and past time, as well as to document cases of intoxication by pesticides and diseases that are associated with pesticide exposure in literature, like cancer, fetus malformation, abortion, and infertility. Therefore, the form sought to identify three main elements in the study population: 1) The status of pesticide exposure in the present; 2 ) The status of pesticide exposure in the past, and; 3 ) Global health profiles and pesticide-related intoxication aspects.

In the first stage of development, we defined the objectives, target population, items approached, and the form format. After a testing and review phase conducted by 4 independent researchers, the final form addressed 60 questions. A pilot study was conducted including 30 women, aiming to allow small revisions and adjustments to make more closed questions and improve the form. Concerning its structure, initially, the form identifies patients' municipality, if they live in the countryside or the city, and the time of residency in these places (years). Subsequently, it asks about pesticide-based agriculture, and if yes, who applies these products, and for how many years. Questions 5 to 15 characterized women and family exposure to pesticides currently, and questions 16 to 27 , in the past. Based on these questions (5-27), it was possible to identify if women were occupationally exposed or not exposed to pesticides, the type of exposure (direct or indirect contact), and how long it lasted. Question 28 to 31 were about symptoms potentially related to pesticide use and whether the family consumed some product cultivated with these substances.

Finally, the form takes into account health aspects from women and their families. Questions about acute intoxication (Question 34 to 42), cancer diagnosis, cases of malformation, abortion, the difficulty of becoming pregnant, and exposure to pesticides before the conception of the children (Question 43 to 60) were included. The data collection instrument was applied by a scientific team previously trained for this purpose. 
To obtain the exposure profiles, all patients attended in the study period were invited to participate. After explaining the purpose of the interview and signing the free and informed consent form, the data collection instrument on the profile of occupational exposure to pesticides was applied by a team trained to carry out standardized data collection. The average interview time was 1 hour, and the interview was conducted in the hospital bed with the patient comfortably allocated, without compromising the medical procedures that were in progress.

\section{Database creation, definition of variables and data analysis}

The responses of the applied form were recorded in a database created in the software IBM SPSS Statistics ${ }^{\circledR}$, version 25 . In SPSS, 65 variables were created that corresponded to 60 questions of the applied form, added to four variables established by the researchers if the patient had a breast cancer diagnosis, related to categorization of disease aggressiveness and familial cancer history. Based on their answers, three occupational pesticide exposure groups were created: 1) directly exposed; 2) indirectly exposed; 3) unexposed (non-occupationally exposed). The directly exposed group consisted of women who responded positively to at least one of the following questions "Do you currently apply pesticides?" (Question 7); "Have you ever applied pesticides?" (Question 15); "Do you wash any family's clothes after the application of pesticides?" (Question 19); Did you wash or washed any family's clothes after the application of pesticides?" (Question 20); "Does your family use pesticides nowadays?" (Question 8); " Did your family use pesticides in the places where you lived?" (Question 14).

The indirectly exposed group consisted of patients who responded positively to at least one of the following questions "Does any neighbor of yours use pesticides?" (Question 23); "Did any neighbor of yours use pesticides?" (Question 24). Thus, we sought to identify whether there was any form of exposure, even if distant to pesticides.

The non-occupationally exposed group consisted of patients who responded negatively to all questions related to the two other groups.

The categorization of breast cancer aggressiveness was defined as high and low, based on combined morphological characteristics of the biopsy (histological degree, index of proliferation, and profile of hormonal receptors expressed in the tumor), and the age of the patient (age). Thus, young patients (below 50 years) and women with tumors without expression of hormonal receptors were categorized as high aggressiveness and the others were grouped as low aggressiveness. Those without a cancer diagnosis were categorized in the category Not applicable for this parameter. The categorization of familial cancer was assessed according to a validated instrument in the Brazilian population ${ }^{29}$.

\section{Expert's form evaluation}

Aiming to get an external expert evaluation of the proposed form, its questions were grouped into five major axes, as shown in Table 1. It was a qualitative evaluation aiming to know some expert opinions about the form. Six scientists, experts in pesticides and health, from different areas and institutions were invited to evaluate the form. Arbitrary values were attributed to each axis, ranging from 1 to 5, being: 1 - Bad, 2 - Regular, 3 - Good, 4 - Very Good, and 5 - Great. These axes were evaluated by experts in the field of agrochemicals and health in Brazil who are connected to public health institutions and universities. The expert panel was selected based on their experiences in pesticide research and public health in both the Paraná state and Brazilian federation. 
Table 1 - Axis evaluated by experts.

\begin{tabular}{|c|c|c|c|c|c|}
\hline $\begin{array}{l}\text { Axis } 1 \text { - To evaluate } \\
\text { the history of } \\
\text { exposure to } \\
\text { pesticides of the } \\
\text { individual and the } \\
\text { family }\end{array}$ & 1( ) Bad & 2( ) Regular & 3( ) Good & 4( ) Very Good & 5( ) Great \\
\hline $\begin{array}{l}\text { Axis } 2 \text { - To evaluate } \\
\text { the current exposure } \\
\text { to pesticides on the } \\
\text { part of the individual } \\
\text { and the family }\end{array}$ & 1( ) Bad & 2( ) Regular & 3( ) Good & 4( ) Very Good & 5( ) Great \\
\hline $\begin{array}{l}\text { Axis } 3 \text { - To evaluate } \\
\text { the family's living } \\
\text { environment }\end{array}$ & 1( ) Bad & 2( ) Regular & 3( ) Good & 4( ) Very Good & 5( ) Great \\
\hline $\begin{array}{l}\text { Axis } 4 \text { - To evaluate } \\
\text { pesticide poisoning in } \\
\text { individual and family }\end{array}$ & 1( ) Bad & 2( ) Regular & 3( ) Good & 4( ) Very Good & 5( ) Great \\
\hline $\begin{array}{l}\text { Axis } 5 \text { - To evaluate } \\
\text { diseases possibly } \\
\text { related to pesticides } \\
\text { in the individual and } \\
\text { family }\end{array}$ & 1( ) Bad & 2( ) Regular & 3( ) Good & 4( ) Very Good & 5( ) Great \\
\hline
\end{tabular}

The results from expert analyses are shown in Table 2. Two experts attributed note 3 (Good) for the five axes of the form, justifying their opinions that the evaluation of the cholinesterase enzyme is only valid for organophosphate pesticides and carbamates, shortly after exposure and having an initial baseline parameter, not being an examination of pesticide exposure in general. In addition, the form would not be exploring the results of these exams. Two others attributed note 4 (Very Good), with the caveat of the questionnaire being extensive. One expert evaluated the instrument with a maximum score of 5 (Great) and evaluator 5 attributed note 3 for axis 5 but notes 4 or 5 for the others. Thus, as the qualitative evaluations were positive, there was no need to modify the instrument.

Table 2 - Results of experts' evaluation.

\begin{tabular}{cccccc}
\hline & Axis1 & Axis2 & Axis3 & Axis4 & Axis5 \\
\hline Evaluator $\mathbf{1}$ & 4 & 4 & 4 & 4 & 4 \\
Evaluator $\mathbf{2}$ & 4 & 4 & 4 & 4 & 4 \\
Evaluator $\mathbf{3}$ & 5 & 5 & 5 & 5 & 5 \\
Evaluator $\mathbf{4}$ & 3 & 3 & 3 & 3 & 3 \\
Evaluator 5 & 5 & 5 & 4 & 4 & 3 \\
Evaluator 6 & 3 & 3 & 3 & 3 & 3 \\
Average & 4 & 4 & 4 & 4 & 4 \\
\hline
\end{tabular}

Scores legend: 3 = good, 4 = very good, 5 = great.

\section{RESULTS}

The creation and application of a data collection form allowed us to understand in detail how people living in the Southwest of Paraná are exposed to pesticides throughout their lives. From the application of the questionnaire, we obtained information about the relationship of exposure to pesticides recently, as well as in the past. Of the 315 patients who responded to the form, 217 (69.9\%) live in the urban area and 98 (31.1\%) live in the countryside. The average age of the women who 
answered the forms was 49 years old (ranging from 18 to 79 ) and a total of 265 individuals (84.2\%) have lived some part of their life in the countryside.

According to their rural life history, $70.4 \%$ of the 315 patients were categorized as occupationally exposed to pesticides as they directly manipulated or handled the products or lived in environments where the use of these substances was common in family or neighbors' farms. Pesticides were predominantly applied to soybean, corn, wheat, beans, as well as fruits and vegetables. Among a total of 55 women who answered that they consume products planted with pesticides, the most cited were fruits and vegetables (58.1\%), beans (21.8\%), and corn (14.5\%).

Of the women who answered the form, $12.5 \%$ claim to have already applied or apply pesticides, an unusual practice since men are usually the agrochemicals applicators, and this form of direct occupational exposure is the most severe. About $57 \%$ of the patients were classified in the directly exposed group, $13.3 \%$ in the indirectly exposed group, and $29.5 \%$ were categorized as unexposed (Table 3). Therefore, although only 98 women currently live in the field, 222 women reported some type of exposure to pesticides in their lives (70.4\%).

Table 3 - Characterization of occupational exposure to pesticides in the interviewed population.

\begin{tabular}{|c|c|c|}
\hline Variable & $\begin{array}{l}\text { Number of } \\
\text { individuals }\end{array}$ & $\%$ \\
\hline \multicolumn{3}{|l|}{ Exposure } \\
\hline Direct & 180 & 57.1 \\
\hline Indirect & 42 & 13.3 \\
\hline Non-exposed & 93 & 29.5 \\
\hline \multicolumn{3}{|c|}{ Laundering of clothes after pesticide pulverization } \\
\hline Yes & 97 & 31.1 \\
\hline No & 215 & 67.1. \\
\hline \multicolumn{3}{|c|}{ Use of gloves to wash or clean clothes/utensils containing pesticides } \\
\hline Yes & 7 & 2.2 \\
\hline No & 115 & 36.9 \\
\hline Not applicable & 190 & 60.9 \\
\hline \multicolumn{3}{|c|}{$\begin{array}{l}\text { Did your Family use pesticides in the crops? Do your Family use } \\
\text { pesticides in the crops? }\end{array}$} \\
\hline yes & 108 & 35.0 \\
\hline No & 201 & 65.0 \\
\hline \multicolumn{3}{|c|}{ Does any neighbor use pesticides? } \\
\hline Yes & 138 & 44.2 \\
\hline No & 139 & 44.6 \\
\hline Do not know & 35 & 11.2 \\
\hline \multicolumn{3}{|c|}{ Does any member of the family has been diagnosed with cancer? } \\
\hline yes & 213 & 68.3 \\
\hline No & 99 & 31.7 \\
\hline \multicolumn{3}{|c|}{ Did you have had an abortion? } \\
\hline yes & 81 & 26.0 \\
\hline No & 230 & 74.0 \\
\hline \multicolumn{3}{|c|}{ Did any member of your Family have had an abortion? } \\
\hline yes & 75 & 24.1 \\
\hline No & 219 & 70.4 \\
\hline Do not know & 17 & 5.5 \\
\hline \multicolumn{3}{|c|}{ Were you exposed to pesticides during your pregnancies? } \\
\hline Yes & 50 & 16.1 \\
\hline No & 260 & 83.9 \\
\hline \multicolumn{3}{|c|}{ Was your spouse exposed to pesticides before your sons' conception? } \\
\hline Yes & 82 & 26.4 \\
\hline No & 226 & 72.6 \\
\hline Do not know & 3 & 1.0 \\
\hline
\end{tabular}


A total of 179 (56.8\%) of interviewed women had breast cancer diagnosis and, of these, $134 \mathrm{had}$ a highly aggressive disease (high proliferative tumors, early age at diagnosis and/or metastasis), which represents $75 \%$ of the group. When asked about the occurrence of cancer in the family, $68.3 \%$ of women responded positively. Analyzing the number of cases of cancer in family members, a total of 532 cases of the disease were identified.

It has been realized that, of the total number of patients participating in the survey, $73 \%$ live in municipalities that have a consumption of pesticides per cultivated area greater than the national average of $6.7 \mathrm{~kg} / \mathrm{ha}$. Furthermore, $31.1 \%$ of respondents have already washed their family's contaminated clothing, after pesticide application. However, only $2.2 \%$ of respondents who washed clothes wore gloves to handle contaminated clothing.

Of the total number of patients, 35\% report living in places where their family used pesticides, and $44.2 \%$ report that their neighbors used some type of pesticide. These data show that more than $40 \%$ of patients had contact with the rural area and, directly or indirectly, with pesticides widely used in crops. About $84 \%$ of all women have lived in the field at some point in their lives, indicating that they may have been exposed to pesticides at some point.

Of the study patients, 30 patients (9.5\%) already had some pesticide poisoning and 46 patients (14.6\%) reported that their relatives had already suffered some type of poisoning. Regarding the occurrence of spontaneous abortion, $26 \%$ of patients reported that they have already suffered, as well as $24.1 \%$ stated that their relatives also suffered spontaneous abortion. Of the total patients studied, $16.1 \%$ of women reported being exposed to pesticides before conception of their children and $26.4 \%$ stated that their spouses were exposed to pesticides before their conception.

Taking into account that 39 patients (12.4\%) applied pesticides on their crops, we asked about the proper use of personal protective equipment (PPE) during this process, and only 20 (51.2\%) used PPE while working. Considering that 108 patients (35\%) have family members who applied pesticides, it has been reported that $51.8 \%$ of them never used the recommended protections. Among the $48.2 \%$ who has been using it, the most used items are the trio gloves/boots and mask, followed by only boots, only mask, and only gloves. In addition, the family members who applied the most were the interviewees' parents, followed by the spouses, which demonstrates that family work is predominant among the group participating in the research.

\section{DISCUSSION}

Although Brazil is among the largest consumers of pesticides in the world ${ }^{1}$, specific instruments developed to track its impact on Brazilian's health are scarce. If considering specifically the occupationally exposed women's health, as far as we know, there is none. Based on this, the present study proposed to create a specific form, aiming to map with detail how such women are being chronically exposed, and which are the impacts of pesticides on their health.

The main goal of this form was to understand how such people have been exposed to pesticides lifelong, independent of whether the interviewed woman was diagnosed or not with cancer. Questions were conceived in blocks, aiming to get information about the relationships among pesticide exposition, recent and past rural life, exposition during clothes washing or utensils decontamination, and the life history of pesticide-related conditions as cancer, infertility, and abortion. We found a significant number of reports regarding disease occurrence in such women. Specialists have pointed out that pesticide-induced diseases are rising, especially among rural workers, and systemi $\mathrm{c}^{30}$ disorders have been associated with pesticide exposition, mistrusting the safety of agrochemicals. Therefore, the need for scientific instruments that allow understanding this scenario is immediate.

Few studies evaluate the situation of women as rural workers. Culturally, the man has assumed this function, and little attention has been given to the way women can be exposed in the context of family rural work ${ }^{31}$. The handling of pesticides in agriculture is considered a predominantly male activity, however, this does not exempt women and other family 
members from the risk of direct intoxication. It is common for family members to assist in the application and, in most cases, women are responsible for washing the clothes and personal protective equipment that are used in the application. In addition, crops are increasingly closer to homes, where family members move around without personal protective equipment. It is also important to highlight that in the division of labor in agriculture, women occupy a subordinate position and their work appears as an aid, even when they work as much as men or perform the same activities. Thus, because they are only "helping", they are more exposed to risks by handling chemical agents without proper protection ${ }^{32}$.

One relevant finding of our study was that women were not only washing the clothes and decontaminating the utensils employed during pesticide application but also were enrolled in the preparation and dilution of these substances.

A study conducted in Tanzania female rural workers documents the conditions of women occupied in agricultural working. It points out their severe poor conditions of protection against pesticide self-contamination ${ }^{33}$. Other studies have documented the female contamination by pesticides, but focusing on the non-occupational exposition in women that are resident in agricultural areas $34 ; 35$ that get contaminated by occupational, drift, or residential use pathways ${ }^{36}$. High incidence of depression and cancer in farmers' spouses have also been documented ${ }^{37 ; 38}$, as well as higher death occurrence ${ }^{38}$. However, these studies did not consider if there was an occupational exposition of such women. It is not clear in the published studies how these women got contact with pesticides if they were washing contaminated PPEs, applying pesticides in the crops, or just living in the same home of the applicators. This information reinforces the relevance of our study and its contribution to the understanding of the Brazilian reality in this field.

In this prospective study, we observed that most of the patients were categorized as exposed to pesticides, directly or indirectly. Some of them reported that they were responsible for the washing and cleaning of clothes, and it is important to highlight that these women were not using any kind of individual protection equipment, even gloves, during this process. The biggest study performed to characterize the human exposition to pesticides, the Agricultural Health Study ${ }^{39}$, has extensively documented through the last 25 years the impact of chronic exposition to pesticides on farmers' health. This study shows the existence of severe contamination of rural populations during the application, due to the lack of individual protection equipment such as gloves, that could prevent up to $80 \%$ against pesticide exposure.

The dermal exposure to pesticides constitutes an important route of contamination of these rural women. Occupational skin exposure can result in direct injury, immune-mediated skin problems, and systemic effects ${ }^{40}$. In the present study, the capability of agrochemicals to enter the skin may be enhanced by the poor working conditions of the rural workers interviewed, mainly the lack of individual protection equipment during pulverization and laundering.

It has been also noticed that an important percentage of the interviewed women from our study answered that they lived in rural areas surrounded by constant venom application, whether in the houses where they lived or by the neighbors' use of pesticide. The Agricultural Health Study also documented that the rural population exposed in the USA are not only exposed by direct ${ }^{39}$ pesticide pulverization but also due to the proximity of their homes to the crops.

Carelessness in the preparation or application of pesticides can lead to acute poisoning. Among the interviewees, about $15 \%$ reported that their family members had already suffered from some type of poisoning at the moment of handling. However, only $9 \%$ sought some kind of medical care, which confirms the problem of underreporting of cases of acute pesticide poisoning in Brazil ${ }^{41}$.

In the country, the great under-reporting of cases of acute poisoning by pesticides reveals a public health problem. This occurs for different reasons ${ }^{42}$, whether due to the low demand 
for medical care by the exposed population; due to failures at the moment of diagnosis; or by not notifying the Toxicological Information Centers when diagnosed.

Other results also suggest that not only the interviewed women but also their families could be affected by the chronic occupational exposure to pesticides. Reporting of abortion and 532 cancer cases was found in several members of the studied families, which is corroborated by numerous studies published in Brazil and presented in detail in one of the most important documents published in Brazil by the Brazilian Association of Public Health: Dossier ABRASCO ${ }^{21}$.

The results presented in our study demonstrate the need to create media strategies to raise awareness of all of the risks related to pesticides, especially for farmers who frequently handle these products. In addition, it is necessary to technically subsidize professionals in the primary care network for the reception, diagnosis, and notification of the population exposed to the acute and chronic effects of pesticides.

In this sense, it is important to mention that there are already some strategies in Brazil through the elaboration of informative booklets for farmers, lectures, and events, including in the state of Paraná. Furthermore, since 2013, the state has structured a working group that has trained professionals in the health sector, seeking to increase and qualify the notifications of exogenous poisoning in the state. An example of this attention to professional training is the Guideline ${ }^{43}$ for assistance to populations exposed to pesticides, which is a document that guides the entire process of clinical care for the intoxicated person, as well as notification in the official agencies. Therefore, the fact that the state of Paraná is the one that registers the most poisonings in the official agencies may be linked to this organizational work by the state. The Ministry of Health has a specific document for this purpose, the Sinan Exogenous Poisoning Investigation Sheet - Information System for Notifiable Diseases (SINAN) ${ }^{44}$, containing guidelines for filling in and good practices for notification in these cases.

Finally, the expert panel evaluation was requested aiming to know if the instrument was able to identify pesticide chronic exposure in potential women breast cancer patients, but in any person too, and retrieved a very positive impression about the proposed instrument. In their opinion, the instrument was well constructed and reached its goals, bringing important data to understand possible causes and consequences of pesticide exposure in this population. Interview forms, despite the purpose of understanding a particular context from the interviewee's point of view, are subjected to biases, especially memory bias if considering that our patients were under emotional distress. This is the main limitation of our study that may affect the interpretation of our findings.

\section{CONCLUSION}

Our data showed that women living in Paraná Southwest have significant occupational exposure to pesticides. The main route of contamination is during clothes washing and equipment decontamination, due to the fact that they do not wear any type of protection gloves. Also, we documented that the profile of breast cancer observed in this population is quite different from that reported in literature, with predominance of tumors with aggressive characteristics. This fact deserves attention and needs to be further investigated in detail. About the instrument, the proposed form reached the objective of understand the main points concerning occupational pesticide exposition in rural women, besides it alerts us to the fact of female contamination in rural families by occupational and daily activities. Moreover, the research highlighted the need to pay attention to the growing incidence of diseases in such populations and their families, probably underreported in the Brazilian public health system. The results also reinforced the need to develop actions about continuing education of these women regarding skin protection during their tasks. As a perspective, our group is now working on a reduced version of the instrument, to be tested in the future as a self-application form, also in the male rural population and in other people than cancer patients. 


\section{REFERENCES}

1. Food and Agriculture Organization of the United Nations - FAO. FAOSTAT [Internet]. Rome: FAO; 2019 [cited 2021 Aug 23]. Available from: http://www.fao.org/faostat/en/\#data/RP/visualize.

2. Schorr B. Extractivism in Latin America: the global-national-local link. Lat Am Res Rev. 2019;54(2):509-16. http://dx.doi.org/10.25222/larr.392.

3. Melgarejo L. Agrotóxicos e Direitos Humanos. In: Burity VTA, editor. Agrotóxicos na América Latina: violações contra o direito humano à alimentação e à nutrição adequadas. Brasília: FIAN Brasil; 2020. p. 23-71.

4. SINDIVEG - Sindicato Nacional da Indústria de Produtos para a Defesa Vegetal. O que você precisa saber sobre defensivos agrícolas [Internet]. São Paulo: SINDIVEG; 2020 [cited 2021 Aug 23]. Available from: https://sindiveg.org.br/wpcontent/uploads/2020/08/SINDIVEG_Paper_REV_FINAL_2020_bxresolucao.pdf

5. IBAMA - Instituto Brasileiro do Meio Ambiente e dos Recursos Naturais Renováveis. Relatórios de Comercialização de Agrotóxicos [Internet]. Brasília: IBAMA; 2021 [cited 2021 Aug 23]. Available from: http://www.ibama.gov.br/agrotoxicos/relatorios-de-comercializacao-de-agrotoxicos/

6. Garcia FP, Ascencio SYC, Oyarzun JCG, Hernandez AC, Alavarado PV. Pesticides: classification, uses and toxicity. Measures of exposure and genotoxic risks. J Res Environ Sci Toxicol. 2012;1(11):27993.

7. Pignati WA, Lima FANS, Lara SS, Correa MLM, Barbosa JR, Leão LHC, Pignatti, MG. Distribuição espacial do uso de agrotóxicos no Brasil: uma ferramenta para a Vigilância em Saúde. Ciênc Saúde Colet. 2017;22(10):3281-93. http://dx.doi.org/10.1590/1413-812320172210.17742017

8. Silva AMC, Campos PHN, Mattos IE, Hajat S, Lacerda EM, Ferreira MJM. Environmental exposure to pesticides and breast cancer in a region of intensive agribusiness activity in Brazil: a case-control study. Int J Environ Res Public Health. 2019;16(20):3951. http://dx.doi.org/10.3390/ijerph16203951. PMid:31627286.

9. Engel LS, Werder E, Satagopan J, Blair A, Hoppin JA, Koutros S, Lerro CC, Sandler DP, Alavanja MC, Beane Freeman LE. Insecticide use and breast cancer risk among farmers' wives in the agricultural health study. Environ Health Perspect. 2017;125(9):097002. http://dx.doi.org/10.1289/EHP1295. PMid:28934092.

10. Andreotti $\mathrm{G}$, et al. Occupational pesticide use and risk of renal cell carcinoma in the agricultural health study. Environ Health Perspect. 2020;128(6):067011. http://dx.doi.org/10.1289/EHP6334. PMid:32692250.

11. Buralli RJ, Ribeiro H, Iglesias V, Muñoz-Quezada MT, Leão RS, Marques RC, Almeida MMC, Guimarães JRD. Occupational exposure to pesticides and health symptoms among family farmers in Brazil. Rev Saude Publica. 2020;54:133. http://dx.doi.org/10.11606/s1518-8787.2020054002263. PMid:33331527.

12. Shrestha $S$, et al. Pesticide use and incident hypothyroidism in pesticide applicators in the agricultural health study. Environ Health Perspect. 2018;126(9):097008. http://dx.doi.org/10.1289/EHP3194. PMid:30256155.

13. Parks CG, Santos ASE, Lerro CC, DellaValle CT, Ward MH, Alavanja MC, Berndt SI, Freeman LEB, Sandler DP, Hofmann JN. Lifetime pesticide use and antinuclear antibodies in male farmers from the agricultural health study. Front Immunol. 2019;10:1476. http://dx.doi.org/10.3389/fimmu.2019.01476. PMid:31354699.

14. Sak ZHA, Kurtuluş Ş, Ocakli B, Töreyin ZN, Bayhan I, Yeşilnacar Mi, Akgün M, Arbak P. Respiratory symptoms and pulmonary functions before and after pesticide application in cotton farming. Ann Agric Environ Med. 2018;25(4):701-7. http://dx.doi.org/10.26444/aaem/99561. PMid:30586963.

15. Thiombane M, Petrik A, Bonito M, Albanese S, Zuzolo D, Cicchella D, Lima A, Qu C, Qi S, Vivo B. Status, sources and contamination levels of organochlorine pesticide residues in urban and agricultural areas: a preliminary review in central-southern Italian soils. Environ Sci Pollut Res Int. 2018;25(26):26361-82. http://dx.doi.org/10.1007/s11356-018-2688-5. PMid:29981022.

16. Bhandari G, Atreya K, Scheepers PTJ, Geissen V. Concentration and distribution of pesticide residues in soil: non-dietary human health risk assessment. Chemosphere. 2020;253:126594. http://dx.doi.org/10.1016/j.chemosphere.2020.126594. PMid:32289601. 
17. Veiga M, Silva DM, Veiga LBE, Faria MVC. Análise da contaminação dos sistemas hídricos por agrotóxicos numa pequena comunidade rural do Sudeste do Brasil. Cad Saude Publica. 2006;22(11):2391-9. http://dx.doi.org/10.1590/S0102-311X2006001100013. PMid:17091176.

18. Zhou Y, Wu J, Wang B, Duan L, Zhang Y, Zhao W, Wang F, Sui Q, Chen Z, Xu D, Li Q, Yu G. Occurrence, source and ecotoxicological risk assessment of pesticides in surface water of Wujin District (northwest of Taihu Lake), China. Environ Pollut. 2020;265(Pt A):114953.

19. Lopes CVA, Albuquerque GSC. Desafios e avanços no controle de resíduos de agrotóxicos no Brasil: 15 anos do Programa de Análise de Resíduos de Agrotóxicos em Alimentos. Cad Saude Publica. 2021;37(2):e00116219. http://dx.doi.org/10.1590/0102-311x00116219. PMid:33624737.

20. WHO - World Health Organization. WHO guideline on health workforce development, attraction, recruitment and retention in rural and remote areas [Internet]. Geneva: WHO; 2021 [cited 2021 Aug 23]. Available from: https://www.who.int/publications/i/item/9789240024229

21. Carneiro F, Rigotto R, Augusto L, Friedrich K, Búrigo A. Dossiê ABRASCO: um alerta sobre os impactos dos agrotóxicos na saúde. Rio de Janeiro: EPSJV; 2015.

22. IARC - International Agency for Research on Cancer. IARC Monographs Volume 112: evaluation of five organophosphate insecticides and herbicides [Internet]. Lyon: IARC; 2015 [cited 2021 Aug 23]. Available from: https://publications.iarc.fr/_publications/media/download/6083/ec47b45697ec10087638e430c5b5 73d462a32143.pdf

23. Paraná. SIAGRO - Sistema de Controle do Comércio e Uso de Agrotóxicos no Estado do Paraná. Relatório de Comercialização 2013-2019 [Internet]. Curitiba: SIAGRO; 2020 [cited 2021 Aug 23]. Available from: http://www.adapar.pr.gov.br/sites/adapar/arquivos_restritos/files/migrados/File/GSV/Siagro/dados _siagro_19.xls

24. Gaboardi SC, Candiotto LZP, Ramos LM. An outline of the use of agrochemicals in southwestern Paraná (2011-2016). Rev NERA. 2019;46(22):13-40. http://dx.doi.org/10.47946/rnera.v0i46.5566.

25. IPARDES - Instituto Paranaense de Desenvolvimento Econômico e Social. Base de dados do estado [Internet]. Curitiba: IPARDES; 2017 [cited 2021 Aug 23]. Available from: http://www.ipardes.gov.br/imp/index.php

26. IBGE - Brazilian Institute of Geography and Statistics. Indicadores de Desenvolvimento Sustentável [Internet]. Rio de Janeiro: IBGE; 2015 [cited 2021 Aug 23]. Available from: https://biblioteca.ibge.gov.br/visualizacao/livros/liv94254.pdf

27. IBGE - Brazilian Institute of Geography and Statistics. Censo Agro 2017. [Internet]. Rio de Janeiro: IBGE; 2017 [cited 2021 Aug 23]. Available from: https://censoagro2017.ibge.gov.br/templates/censo_agro/resultadosagro/index.html

28. Marcelino AF, Wachtel CC, Ghisi NC. Are our farm workers in danger? Genetic damage in farmers exposed to pesticides. Int J Environ Res Public Health. 2019;16(3):358. http://dx.doi.org/10.3390/ijerph16030358. PMid:30691246.

29. Prolla CMD, Silva PS, Netto CBO, Goldim JR, Ashton-Prolla P. Knowledge about breast cancer and hereditary breast cancer among nurses in a public hospital. Rev Lat Am Enfermagem. 2015;23(1):90-7. http://dx.doi.org/10.1590/0104-1169.0185.2529. PMid:25806636.

30. Nicolopoulou-Stamati P, Maipas S, Kotampasi C, Stamatis P, Hens L. Chemical pesticides and human health: the urgent need for a new concept in agriculture. Front Public Health. 2016;4:148. http://dx.doi.org/10.3389/fpubh.2016.00148. PMid:27486573.

31. Bezerra GJ, Schlindwein MM. Agricultura familiar como geração de renda e desenvolvimento local: uma análise para Dourados, MS, Brasil. Interações. 2017;18(1):3-15. http://dx.doi.org/10.20435/1984-042X-2016-v.18-n.1(01).

32. Buaski JP, Magni C, Fujinaga Cl, Gorski LP, De Conto J. Exposure of tobacco farm working mothers to pesticides and the effects on the infants' auditory health. Rev CEFAC. 2018;20(4):432-41. http://dx.doi.org/10.1590/1982-021620182042218.

33. Mrema EJ, Ngowi AV, Kishinhi SS, Mamuya SH. Pesticide exposure and health problems among female horticulture workers in Tanzania. Environ Health Insights. 2017;11:1-13. http://dx.doi.org/10.1177/1178630217715237. PMid:28690397. 
34. Deziel NC, Friesen MC, Hoppin JA, Hines CJ, Thomas K, Freeman LEB. A Review of nonoccupational pathways for pesticide exposure in women living in agricultural areas. Environ Health Perspect. 2015;123(6):515-24. http://dx.doi.org/10.1289/ehp.1408273. PMid:25636067.

35. Deziel NC, et al. An algorithm for quantitatively estimating non-occupational pesticide exposure intensity for spouses in the Agricultural Health Study. J Expo Sci Environ Epidemiol. 2019;29(3):34457. http://dx.doi.org/10.1038/s41370-018-0088-z. PMid:30375516.

36. Beseler C, Stallones L, Hoppin JA, Alavanja MCR, Blair A, Keefe T, Kamel F. Depression and pesticide exposures in female spouses of licensed pesticide applicators in the agricultural health study cohort. J Occup Environ Med. 2006;48(10):1005-13. http://dx.doi.org/10.1097/01.jom.0000235938.70212.dd. PMid:17033500.

37. Shrestha S, Parks CG, Goldner WS, Kamel F, Umbach DM, Lerro CC, Koutros S, Hoffmann JN, Freeman LEB, Sandler DP. Incident thyroid disease in female spouses of private pesticide applicators. Environ Int. 2018;118:282-92. http://dx.doi.org/10.1016/j.envint.2018.05.041. PMid:29908479.

38. Goldner WS, Sandler DP, Yu F, Hoppin JA, Kamel F, LeVan TD. Pesticide use and thyroid disease among women in the agricultural health study. Am J Epidemiol. 2010;171(4):455-64. http://dx.doi.org/10.1093/aje/kwp404. PMid:20061368.

39. AHS - Agricultural Health Study. About the study [Internet]. Bethesda: AHS; 2021 [cited 2021 Aug 23] Available from: https://aghealth.nih.gov/about/

40. Anderson SE, Meade BJ. Potential health effects associated with dermal exposure to occupational chemicals. Environ Health Insights. 2014;8(suppl 1):51-62. http://dx.doi.org/10.4137/EHI.S15258. PMid:25574139.

41. Brasil. Ministério da Saúde. Relatório Nacional de Vigilância em Saúde de Populações Expostas a Agrotóxicos. Brasília: Ministério da Saúde; 2018.

42. Taveira BLS, Albuquerque GSC. Análise das notificações de intoxicações agudas, por agrotóxicos, em 38 municípios do estado do Paraná. Saúde Debate. 2018; 42(spe4): 211-222. https://doi.org/10.1590/0103-11042018S417

43. Paraná. Secretaria de Estado da Saúde do Paraná. Linha guia da atenção às populações expostas aos agrotóxicos. Curitiba: Secretaria de Estado da Saúde; 2018.

44. Brasil. Ministério da Saúde. Secretaria de Vigilância em Saúde. Departamento de Vigilância em Saúde Ambiental e Saúde do Trabalhador. Instruções para preenchimento da Ficha de Investigação de Intoxicação Exógena Sinan - Sistema de Informação de Agravos de Notificação [recurso eletrônico] / Ministério da Saúde, Secretaria de Vigilância em Saúde, Departamento de Vigilância em Saúde Ambiental e Saúde do Trabalhador. Brasília: Ministério da Saúde; 2018.

\section{Authors' contributions:}

All authors equally contributed to the study. 


\section{SUPPLEMENTARY MATERIAL}

The complementary information is available at https://sucupira.capes.gov.br/sucupira/public/consultas/coleta/trabalhoConclusao/viewTrab alhoConclusao.jsf?popup=true\&id_trabalho=10956083 